Monika Plaziak, Tomasz Rachwał

Uniwersytet Pedagogiczny

w Krakowie

\title{
„Przedsiębiorczy region" - zarys koncepcji w świetle analizy roli przedsiębiorczości w krajowej strategii rozwoju regionalnego
}

\section{"Entrepreneurial region" - an outline of the concept in the light of an analysis of the role of entrepreneurship in the national strategy of regional development}

\section{Streszczenie}

Rozwój postaw przedsiębiorczych w społeczeństwie oraz przedsiębiorczości jako wyrazu aktywności przedsiębiorców i menedżerów firm jest uważany za ważny czynnik rozwoju społeczno-gospodarczego regionów, szczególnie w krajach transformujących swoje gospodarki. Przedsiębiorczość odgrywa rolę głównie w przyspieszeniu wzrostu gospodarczego, generowaniu impulsów do przemian strukturalnych gospodarki danego regionu oraz łagodzi skutki strukturalnego bezrobocia poprzez samozatrudnienie osób pozostających bez pracy. W tym kontekście ważne jest pytanie, jakie jest miejsce przedsiębiorczości w strategiach rozwoju regionalnego. Przedmiotem artykułu jest prezentacja wyników analizy polskiej Krajowej Strategii Rozwoju Regionalnego 2010-2020: Regiony, Miasta, Obszary wiejskie pod kątem obecności zapisów odnoszących się do przedsiębiorczości jako ważnego czynnika rozwoju regionalnego. Na tle wyników analiz podjęto próbę zarysowania koncepcji ,,przedsiębiorczego regionu”.
\end{abstract}

\begin{abstract}
Development of entrepreneurial attitudes in the society and entrepreneurship as an expression of activity of entrepreneurs and managers of companies is considered as a particularly important factor of the socio-economic development of regions, particularly in countries, which transform their economies. Entrepreneurship plays its role mostly in accelerating the economic growth, generating pulses to the structural transformation of regional economy and alleviating the consequences of structural unemployment through self-employment of the unemployed. In this context, it is important to ask about the place of entrepreneurship in regional development strategies. The subject of the article is to present the results of analysis of the Polish National Strategy of Regional Development 2010-2020: Regions, Cities, Rural Areas with respect of having provisions related to entrepreneurship as an important factor stimulating the regional development. Against the background of results of the analysis, the authors attempted to outline the concept of "entrepreneurial region".
\end{abstract}

Słowa kluczowe: krajowa strategia rozwoju regionalnego; Polska; przedsiębiorczość; przedsiębiorczy region; rozwój regionalny

Keywords: entrepreneurship; entrepreneurial region; national strategy of regional development; Poland; regional development

\section{Wstęp}

Przedsiębiorczość jest powszechnie traktowana jako jeden z podstawowych czynników rozwoju społecznego i gospodarczego w układach przestrzennych o różnej skali (krajowych, regionalnych, lokalnych). Szczególnego znaczenia nabiera ona w Polsce i innych krajach euro- 
pejskich transformujących swoje gospodarki, zwłaszcza w warunkach kryzysu gospodarczego, odgrywając dużą rolę w utrzymaniu dynamiki i przyspieszeniu wzrostu gospodarczego oraz łagodzeniu skutków bezrobocia strukturalnego. Jak wskazali Z. Zioło i T. Rachwał (2012), wynika to $\mathrm{z}$ faktu coraz większej roli przedsiębiorcy w gospodarce, podejmującego określone decyzje dotyczące lokalizacji i kierunków rozwoju przedsiębiorstwa, które poprzez swoje relacje w układach przestrzennych wpływa na rozwój bądź recesję tych układów. Procesy przemian społeczno-gospodarczych i kulturowych w różnego typu układach przestrzennych wynikają z podejmowania określonych decyzji, u podstaw których leży przedsiębiorczość konkretnych osób czy zespołów, w tym przedsiębiorców i przedstawicieli władz samorządowych i centralnych. Tym samym przedsiębiorczość można traktować jako jeden z podstawowych czynników przemian przyczyniający się do podnoszenia pozycji konkurencyjnej tych układów. Z postawami przedsiębiorczymi mieszkańców związana jest także kreatywność i zdolność do wdrażania nowych idei do praktyki gospodarczej, co sprzyja rozwojowi innowacyjności, traktowanej jako jeden z podstawowych czynników rozwoju społeczno-gospodarczego i konkurencyjności regionów w warunkach budowy gospodarki opartej na wiedzy (Gal 2005; Borowiec i in. 2009; Dorocki, Jenner 2009; Golejewska 2012; Rachwał 2012; Zioło 2012a; Makieła 2013; Perło, Dębkowska 2013). Warto przy tym podkreślić za M. Kosałą (2015) i K. Wachem (2015), że innowacyjność i orientacja przedsiębiorcza firm są także jednymi z podstawowych czynników wpływających na umiędzynarodowienie działalności tych przedsiębiorstw, co wpływa jednocześnie na intensyfikację powiązań regionów krajowych z zagranicznymi i podnoszenie ich konkurencyjności w układzie międzynarodowym. W tej sytuacji powstaje pytanie, na ile dokumenty strategiczne odnoszące się do rozwoju regionalnego i związane z tym działania władz publicznych uwzględniają tę znaczącą rolę przedsiębiorczości w rozwoju tych układów. Wszak, jak zauważyła M. Niedziółka (2010), rozwój regionalny jest kluczowym aspektem polityki ekonomicznej, jednocześnie zwracając uwagę, że choć to rząd odgrywa najważniejszą rolę $\mathrm{w}$ procesie projektowania strategii rozwoju regionalnego, to jednak efektywne wdrożenie polityki regionalnej wymaga przede wszystkim udziału potencjału lokalnego, co jest możliwe dzięki procesom decentralizacji władzy publicznej. Niemniej jednak punktem wyjścia jest dobra strategia rozwoju regionalnego.

W świetle powyższych przesłanek celem artykułu jest identyfikacja miejsca przedsiębiorczości w nowym paradygmacie polityki regionalnej oraz strategii rozwoju regionalnego na podstawie Krajowej Strategii Rozwoju Regionalnego 2010-2020: Regiony, Miasta, Obszary wiejskie (KSRR) (2010) i próba odpowiedzi na pytanie, czy zgodnie z KSRR przedsiębiorczość jest ważnym czynnikiem pobudzania rozwoju regionalnego. W pracy podjęto także próbę zarysowania koncepcji regionu przedsiębiorczego i sformułowania wniosków dla polityki regionalnej, której podstawą, jak się wydaje, powinna być właśnie koncepcja regionu przedsiębiorczego. Główną metodą badawczą jest analiza dokumentów (zapisów KSRR) oraz piśmiennictwa. Dla celów analizy przyjęto szeroką definicję przedsiębiorczości, obejmującą nie tylko funkcję przedsiębiorcy czy przedsiębiorstw sektora MŚP, lecz także przedsiębiorczość jako cechę osobowości i postawę człowieka.

Problematyka roli przedsiębiorczości w rozwoju regionalnym w świetle literatury przedmiotu Problematyka roli przedsiębiorczości w rozwoju regionalnym była przedmiotem zainteresowania wielu badaczy, zarówno w kraju, jak i za granicą, gdzie od lat podejmuje się badania w tym zakresie (np. Klasik 2005; Ochojski i in. 2005; Wach 2008; Acs 2010; Kola-Bezka 2010; Kuciński 2010; Fritsch 2011; Wyrwich 2012; Zioło, Rachwał 2012; Makieła 2013; Qian i in. 2013). 
Autorzy w pierwszej kolejności zwracają uwagę na niejednoznaczność i wielowymiarowość bądź polisemiczność (por. Brzozowski 2007) pojęcia przedsiębiorczości, którego definicja podlega ciągłej ewolucji (por. Ochojski i in. 2005). A. Gaweł (2007) podkreśla nawet, że ekonomiści są zgodni, iż brakuje kompleksowej i jednolitej teorii przedsiębiorczości czy wręcz jej definicji, co jest wynikiem wielowątkowości podejmowanych zagadnień w pracach z tego zakresu i interdyscyplinarnego charakteru tego fenomenu. Warto przy tym zwrócić uwagę za K. Wachem (2014a), że przedsiębiorczość jest rozpatrywana w literaturze przedmiotu właśnie jako fenomen społeczny oraz dyscyplina naukowa. W badaniach naukowych (Wach 2012, 2014a) wyróżnia się przede wszystkim następujące funkcje przedsiębiorczości: funkcję rynku, funkcję indywidualnego przedsiębiorcy, funkcję osobowości oraz funkcje mikro-, małych i średnich przedsiębiorstw. W tym kontekście ważne jest więc ustalenie, jak rozumiana jest przedsiębiorczość w rozważaniach dotyczących rozwoju regionalnego. Uzasadnionym wydaje się być pogląd, że w literaturze przedmiotu podejmuje się głównie problematykę przedsiębiorczości rozumianej jako tworzenie i rozwój nowych firm (por. Gaweł 2013) bądź aktywność małych i średnich przedsiębiorstw jako czynnik rozwoju regionalnego (por. Klasik 2005). Warto podkreślić, że w ostatnim czasie podejmowana jest także problematyka wpływu przedsiębiorczości mieszkańców (jako cechy osobowości) na rozwój społeczno-gospodarczy. W tej sytuacji podkreśla się znaczenie edukacji dla przedsiębiorczości (Wach 2007, 2013, 2014b; Kurek, Rachwał 2009; Zioło i in. 2015), w której procesie kształtuje się postawy przedsiębiorcze mieszkańców. Rozważania odnoszące się do istoty i definicji przedsiębiorczości skłaniają również ku zastanowieniu się, na ile uprawnione jest stosowanie terminu ,przedsiębiorczość” (,przedsiębiorczy/przedsiębiorcza”) w odniesieniu do układów terytorialnych. W literaturze przedmiotu coraz częściej przymiotnik ,„przedsiębiorczy” odnosi się nie tylko do człowieka, lecz także do różnego typu organizacji (analogicznie np. do organizacji uczącej się lub inteligentnej). Coraz częściej też określenia o charakterze osobowym przypisywane są układom przestrzennym. Dobrym przykładem jest tu koncepcja inteligentnego miasta - smart city (Cieślik, Koładkiewicz 2014). A. Ochojski i in. (2005) zwracają uwagę za Z. Barczykiem (2004), że coraz częściej mówi się nie tylko o przedsiębiorczym kierowaniu (entrepreneurial leadership), zarządzaniu czy współrządzeniu (entrepreneurial governance), lecz także o przedsiębiorczej gospodarce, przedsiębiorczej społeczności, przedsiębiorczym mieście (entrepreneurial city) czy przedsiębiorczych gminach/samorządach lokalnych (entrepreneurial municipalities). Te dwa ostatnie określenia są od dosyć dawna używane w literaturze przedmiotu (zob. Hall, Hubbard 1996; Zheng 2011). Jednak w tym kontekście warto się zastanowić, na ile chodzi tu o ,przedsiębiorczość” układów przestrzennych o różnej skali czy raczej o „ducha przedsiębiorczości” władz tych jednostek (por. Jarczewski 2007). Pojęcie przedsiębiorczego regionu jest rzadziej używane, choć również spotykane w literaturze przedmiotu (np. Georgellis, Wall 2000; Klasik 2005; Berggren, Dahlstrand 2009). Pojęcie to zostało spopularyzowane w Europie dzięki projektowi European Entrepreneurial Region (EER), w ramach którego wskazane zostają 1-3 regiony unijne, które opracowały wyjątkowe wizje dotyczące rozwoju przedsiębiorczości, niezależnie od wielkości, bogactwa, kompetencji i aktualnego poziomu konkurencyjności tych regionów. Regiony charakteryzujące się najbardziej przekonującymi i perspektywicznymi opracowaniami (propozycjami) strategii w zakresie rozwoju przedsiębiorczości uzyskują specjalny tytuł (label) - European Entrepreneurial Region of the Year (Europejski Region Przedsiębiorczości Roku). W 2014 roku tytuł ten otrzymały: region stołeczny Portugalii - Lizbona, Irlandia Północna i hiszpańska Walencja. Łącznie w latach 2011-2014 tytuł ten przyznano 15 regionom, przy czym żadnemu z Polski (EER 2014). 
Rozpatrując kwestię roli przedsiębiorczości w rozwoju regionalnym, zdaniem K. Kucińskiego (2010), pojawiają się dwa podstawowe problemy badawcze i praktyczne: po pierwsze, jak istniejące w poszczególnych regionach uwarunkowania prowadzania działalności gospodarczej (przyrodnicze, społeczne, ekonomiczne, techniczne, kulturowe i instytucjonalne) wpływają na przedsiębiorczość, a po drugie - jak poprzez kształtowanie i rozwój przedsiębiorczości można wpływać na poziom i strukturę gospodarki poszczególnych regionów, tak aby stawały się bardziej spójnymi elementami narodowej, europejskiej i globalnej przestrzeni ekonomicznej. Z punktu widzenia celu niniejszej pracy kluczowe jest to drugie zagadnienie, niemniej jednak należy zwrócić uwagę, że podejmowane prace badawcze w zakresie uwarunkowań rozwoju przedsiębiorczości prowadzą do odkrywania coraz bardziej złożonych zależności, a pojemność tej problematyki wydaje się niewyczerpana. Analizowane są coraz to nowe czynniki tkwiące w otoczeniu zewnętrznym ('światowym, europejskim, krajowym) oraz w przestrzeni regionu wpływające na rozwój przedsiębiorczości. W ostatnim czasie szczególną uwagę zwraca się na uwarunkowania kulturowe (por. Glinka 2008; Brdulak, Jakubik 2010), a także na te związane z ogólnoświatowym kryzysem gospodarczym (Zioło 2013). Dla celów niniejszego artykułu szczególne znaczenie ma tu drugi, wyróżniony przez K. Kucińskiego (2010) obszar badawczy, ukierunkowany na analizy, jak przez świadome, z użyciem odpowiednich instrumentów polityki, kształtowanie i rozwój przedsiębiorczości można wpływać na poziom i strukturę gospodarki poszczególnych regionów. W tym zakresie powszechne jest przekonanie, że podstawą prosperity regionów jest przedsiębiorczość, co oznacza - zdaniem A. Klasika (2005), że źródłem bogactwa regionów są przedsiębiorczy ludzie. Autor ten zwraca uwagę, iż łączne ujęcie zdolności przedsiębiorczych i konkurencyjnych regionów pozwala je traktować jako współdeterminanty ich trwałego rozwoju gospodarczego. Można zatem wnosić, że rozwój przedsiębiorczości wpływa na podniesienie konkurencyjności regionów, co podkreśla wielu autorów, między innymi Z. Makieła (2013), który stwierdza, że celem przedsiębiorczości i innowacyjności regionalnej jest przede wszystkim wzrost konkurencyjności gospodarki regionów. Zatem, jeśli w strategii rozwoju regionalnego, opartej na tak zwanym nowym paradygmacie polityki regionalnej, konkurencyjność stanowi, obok spójności i sprawności, jeden z podstawowych filarów triady tej polityki, należy oczekiwać, że przedsiębiorczość będzie zajmować znaczące miejsce, zarówno w analizie uwarunkowań rozwoju regionalnego, jak i w celach (głównych i szczegółowych) oraz działaniach i wskaźnikach monitorowania osiągnięcia celów.

\section{Miejsce przedsiębiorczości w KSRR}

Analiza zapisów KSRR (2010) wskazuje na uwzględnienie problematyki przedsiębiorczości w polskiej strategii rozwoju regionalnego. Przedsiębiorczość w kontekście otoczenia biznesowego została uwzględniona w nowym paradygmacie polityki regionalnej, który wprowadza nowe narzędzia tej polityki (zamiast dotychczasowych subsydiów i pomocy publicznej koncentruje się na otoczeniu biznesowym wraz ze zintegrowanymi instrumentami „miękkimi” i „twardymi” oraz kapitałem społecznym, sieciowaniem i lepszą koordynacją) (KSSR 2010: 15). Ponadto w nowym paradygmacie uwzględniono nowych głównych aktorów (dawniej był to rząd i samorząd województwa, aktualnie - obok wszystkich szczebli administracji i aktorów społecznych zostali wymienieni także przedstawiciele biznesu).

Na 11 obszarów wyzwań strategicznych żaden nie zawiera w swej formule akcentu z zakresu rozwoju przedsiębiorczości (KSSR 2010: 24). Jedynie w prezentacji dotyczącej wzajemnych relacji poszczególnych wyzwań strategicznych (terytorialnych i sektorowych) uwzględniono zwiększenie powiązań środowisk biznesu, edukacji, nauki i kultury jako wypadkową 
relacji między lepszym wykorzystaniem potencjałów najważniejszych ośrodków miejskich do kreowania wzrostu i zatrudnienia a poprawą jakości zasobów pracy (KSSR 2010: 25).

Przedsiębiorczość w wymiarze oceny poziomu jej rozwoju, a także konieczności progresji tego poziomu pojawia się natomiast w opisie niektórych wyzwań strategicznych:

Wyzwanie 2. Zapewnienie spójności wewnętrznej kraju. Niedopuszczenie do nadmiernych zróżnicowań przestrzennych. Podpunkt b) zwiększenie perspektyw rozwojowych na zapóźnionych obszarach wiejskich o najgorszych wskaźnikach sytuacji społeczno-gospodarczej $i$ najniższym poziomie dostępu mieszkańców do usług i dóbr warunkujących możliwości rozwojowe - niska przedsiębiorczość (obok bardzo wysokiego zatrudnienia w rolnictwie, dużego odsetka osób o niskim poziomie wykształcenia i niskich kwalifikacjach zawodowych, niskiego poziomu instytucji publicznych, w tym administracji, niskiego poziomu inwestycji i niskiego poziomu wyposażenia infrastrukturalnego) jest wymieniana jako „niekorzystny” wskaźnik możliwości rozwojowych (KSSR 2010: 32). „Słabe wskaźniki przedsiębiorczości” (równolegle $\mathrm{z}$ bezrobociem i nadmiernym zatrudnieniem w nieefektywnym rolnictwie) stanowią przyczynę problemów społecznych, a te prowadzą do degradacji gospodarczej na znacznym obszarze terenów wiejskich w województwach wschodniej i północnej Polski (KSRR 2010: 34). Konieczne jest między innymi zwiększenie dostępu do usług (w tym doradztwa biznesowego), co pozwoli na obszarach wiejskich o najsłabszych perspektywach rozwoju na zmniejszenie zróżnicowań w stosunku do średniej krajowej i sytuacji w miastach (KSRR 2010: 34).

Wyzwanie 2. Podpunkt c) przeciwdziałanie zagrożeniu utraty dotychczasowych funkcji społeczno-gospodarczych niektórych obszarów miejskich i innych obszarów - niski poziom przedsiębiorczości wymieniony został jako jedno z negatywnych zjawisk gospodarczych (obok bezrobocia i niskiej jakości infrastruktury technicznej) w odniesieniu do niektórych obszarów miejskich (Szczecin, Łódź) i zurbanizowanych obszarów przemysłowych (Konurbacja Górnośląska) (KSRR 2010: 35).

Wyzwanie 2. Podpunkt d) zwiększanie potencjału rozwojowego i przeciwdziałanie marginalizacji obszarów przygranicznych - wskazano na rozwój przedsiębiorczości jako efekt znikających ograniczeń w przepływie dóbr, osób, kapitałów i usług, w odniesieniu do pogranicza zwłaszcza z Niemcami, Czechami i Słowacją (KSRR 2010: 36).

Wyzwanie 5. Poprawa jakości zasobów pracy - stwierdzono, że poprawa w tym zakresie powinna nastąpić między innymi poprzez zwiększenie w dużych miastach powiązań środowisk biznesu, edukacji, nauki i kultury (klastry, networking) (KSRR 2010: 51).

Wyzwanie 8. Wykorzystanie potencjału kulturowego i turystycznego dla rozwoju regionalnego - rozwój przedsiębiorczości został tutaj wymieniony (obok generowania nowych miejsc pracy, podniesienia jakości życia lokalnych społeczności, podwyższenia konkurencyjności regionów) jako element zwiększania dynamiki rozwoju społeczno-ekonomicznego kraju w wyniku rozwoju funkcji turystycznych na bazie atutów kulturowych i przyrodniczych (KSRR 2010: 62).

Przedsiębiorczość została wyszczególniona (jednak tylko w przypisach) w odniesieniu do zasad polityki regionalnej jako jedna z cech decydujących o suwerenności jednostki ludzkiej (wraz ze swobodami obywatelskimi i gospodarczymi, innowacyjnością, prawem do autonomii i samorealizacji, poczuciem odpowiedzialności za jakość własnego życia i za dobro wspólne, aktywnością społeczną i polityczną sprzyjającą ładowi demokratycznemu), będącej jedną z determinant społeczeństwa demokratycznego (KSRR 2010: 51).

Przedsiębiorczość została uwzględniona w Wizji rozwoju regionalnego Polski do roku 2020 w podpunkcie Spójność gospodarcza, społeczna i terytorialna - w obszarach o najniższym poziomie rozwoju ma nastąpić rozwój przedsiębiorczości (wraz ze wzrostem aktywności go- 
spodarczej, napływem inwestycji, zwiększeniem liczby i poprawą jakości miejsc pracy) w wyniku wsparcia procesów urbanizacyjnych, poprawy jakości edukacji oraz zwiększenia dostępu do usług publicznych (KSRR 2010: 84).

Spośród zdefiniowanych trzech celów polityki regionalnej do 2020 roku aspekt przedsiębiorczości został zasygnalizowany w opisie celu 1. - Wspomaganie wzrostu konkurencyjności regionów (, konkurencyjność”), w którym przewidziano horyzontalne wsparcie w kierunku rozwoju konkurencyjności całych regionów, prowadzącej do integracji funkcjonalnej obszarów województw. Wsparcie dotyczyć będzie obszarów położonych poza funkcjonalnymi ośrodkami wojewódzkimi i doprowadzić ma między innymi do zwiększenia atrakcyjności inwestycyjnej w tym rejonie i rozwoju instytucji otoczenia biznesu (KSRR 2010: 90). Tak marginalne potraktowanie roli przedsiębiorczości w celu odnoszącym się do konkurencyjności w kontekście badań na temat relacji między przedsiębiorczością a konkurencyjnością (por. Klasik 2005) jest dużym zaskoczeniem. Przedsiębiorczość znalazła natomiast swoje miejsce w opisie celu 3. - Tworzenie warunków dla skutecznej, efektywnej i partnerskiej realizacji dziatań rozwojowych ukierunkowanych terytorialnie (,,sprawność). W ramach podniesienia efektywności polityki regionalnej zakłada się odejście od bezpośrednich dotacji bezzwrotnych na rzecz wspierania rozwoju i wykorzystania tak zwanych instrumentów rewolwingowych (funduszy pożyczkowych, poręczeniowych), przynoszących zwrot z poniesionych inwestycji i długoterminowe korzyści gospodarcze i społeczne (KSRR 2010: 91).

W niektórych szczegółowych kierunkach działań odpowiadających poszczególnym celom uwzględniono konieczność rozwoju poziomu przedsiębiorczości.

W kierunkach działań w ramach celu 1. Wspomaganie wzrostu konkurencyjności regionów (, konkurencyjność”), Ad 1.2. Tworzenie warunków dla rozprzestrzeniania procesów rozwojowych i zwiększania ich absorpcji na obszary poza ośrodkami wojewódzkimi, podpunkt Ad 1.2.2. Wspieranie rozwoju i znaczenia miast subregionalnych przewidziano zapewnienie finansowania dla przedsiębiorstw, poprawę jakości i zwiększenie oferty usług okołobiznesowych, świadczonych przez publiczne i niepubliczne instytucje otoczenia biznesu (KSRR 2010: 105). W podpunkcie Ad 1.2.3. Petniejsze wykorzystanie potencjału rozwojowego obszarów wiejskich założono bezpośrednie wsparcie ukierunkowane na rozwój przedsiębiorczości dla osób odchodzących z rolnictwa lub zamierzających zdywersyfikować swoje źródła utrzymania (chodzi tu np. o agroturystykę czy przedsiębiorczość wykorzystującą dziedzictwo kulinarne), co ma przyczynić się do zwiększenia zatrudnienia (KSRR 2010: 108). Przewidziano też wspieranie tworzenia instytucjonalnych warunków do zwiększania inwestycji pozarolniczych na obszarach o niskiej konkurencyjności rolnictwa, co ma doprowadzić do zwiększenia zatrudnienia w sektorze pozarolniczym, między innymi poprzez wspomaganie rozwoju inkubatorów przedsiębiorczości (KSRR 2010: 109). W Ad 1.3. Budowa podstaw konkurencyjności województw - działania tematyczne (horyzontalne) znalazło się siedem grup działań, spośród których dwie wiążą się z rozwojem przedsiębiorczości. W Ad 1.3.3. Zwiększanie możliwości wprowadzania rozwiazań innowacyjnych przez przedsiębiorstwa i instytucje regionalne uwzględniono „partnerski, bezpośredni i powszechny” kontakt świata biznesu z głównymi ośrodkami naukowymi i badawczymi w kraju i na świecie. W ośrodkach regionalnych należy zwiększyć udział środków prywatnych (przedsiębiorstw) w finansowaniu B+R (KSRR 2010: 114). W Ad 1.3.4. Wspieranie rozwoju instytucji otoczenia biznesu (IOB) zakłada się zmianę sposobu wspierania istniejących i nowo zakładanych przedsiębiorstw - ma to polegać nie na bezpośrednim dotowaniu poszczególnych przedsiębiorstw, ale raczej na tworzeniu warunków do rozwoju przedsiębiorstw i na rozwijaniu atrakcyjności inwestycyjnej (KSRR 2010: 114). 
Rozwój przedsiębiorczości znalazł swoje miejsce w kierunkach działań w ramach realizacji celu 2. Budowanie spójności terytorialnej i przeciwdziałanie marginalizacji obszarów problemowych (,spójność”), Ad 2.1. Wzmacnianie spójności w układzie krajowym wraz z następującymi działaniami: wzmacnianie istniejącej sieci miast i wspomaganie urbanizacji, rozwój zasobów ludzkich i kapitału społecznego, tworzenie infrastrukturalnych i instytucjonalnych warunków do zwiększania poziomu inwestycji i wzrostu wydajności pracy (KSRR 2010: 121). Rozwój zasobów ludzkich i kapitału społecznego ma następować między innymi poprzez wspieranie rozwoju przedsiębiorczości (doradztwo, wsparcie i zachęty finansowe, szkolenia) (KSRR 2010: 122). W Ad 2.2. Wspieranie obszarów wiejskich o najniższym poziomie dostępu mieszkańców do dóbr i usług warunkujacych możliwości rozwojowe wskazano na potrzebę zapewnienia partnerstwa i współpracy sektora publicznego i prywatnego (współpraca władz wszystkich szczebli z sektorem przedsiębiorstw), a także na potrzebę propagowania przedsiębiorczości, między innymi poprzez wspieranie tworzenia innowacyjnych przedsiębiorstw na obszarach wiejskich, co umożliwi tam dywersyfikację gospodarczą (KSRR 2010: 125). W Ad 2.3. Restrukturyzacja i rewitalizacja miast i innych obszarów tracacych dotychczasowe funkcje społeczno-gospodarcze zostało przewidziane wsparcie dla ośrodków (miast) znajdujących się w szczególnie trudnej sytuacji ze względu na różne czynniki, w tym niski poziom przedsiębiorczości. Wsparcie to uwzględnia działania nakierowane na poprawę jakości kapitału ludzkiego, między innymi poprzez pobudzanie przedsiębiorczości i innowacyjności (KSRR 2010: 130). W Ad 2.4. Przezwyciężanie niedogodności związanych z położeniem obszarów przygranicznych, szczególnie wzdtuż zewnętrznych granic UE zakłada się wsparcie lokalnej przedsiębiorczości (obok poprawy dostępności do usług i sieci transportowych oraz komunikacyjnych), co ma przyczynić się do rozwoju i promowania wspólnego wykorzystania (przez sąsiadów z państw graniczących) infrastruktury lokalnej, ochrony wspólnego dziedzictwa naturalnego i kulturalnego, turystyki, zapobiegania zagrożeniom naturalnym i technicznym, wsparcia powiązań między obszarami miejskimi i wiejskimi oraz zmniejszania izolacji (KSRR 2010: 132). Wzrost przedsiębiorczości został wymieniony jako jedna z miar sukcesu realizacji celu 2. (KSRR 2010: 136). Zaskakujące wydaje się to, że nie został on uwzględniony jako jedna z miar sukcesu realizacji w celu 1., odnoszącym się do konkurencyjności. Wskaźniki przedsiębiorczości nie zostały jednak zaliczone do wskaźników monitorowania realizacji całej KSRR. Jedynie we wskaźnikach monitorowania celu 1. w zakresie budowy podstaw konkurencyjności województw (działania tematyczne) pojawia się wskaźnik: Liczba nowo zarejestrowanych podmiotów gospodarki narodowej ogółem w sektorze prywatnym, w tym osoby fizyczne prowadzace działalność gospodarczą, spółki handlowe, spótki handlowe z udziałem kapitału zagranicznego. Założono jednak mało realne, około 6-krotne wzrosty wartości tych wskaźników do 2020 roku w porównaniu z rokiem bazowym 2008 (KSRR 2010: 157). W zestawie wskaźników monitorowania celu 2., związanego ze spójnością, pojawia się wskaźnik Liczba podmiotów gospodarki narodowej zarejestrowanych w rejestrze REGON na 1000 mieszkańców $w$ wieku produkcyjnym (15-64 lata), w tym na obszarach strategicznej interwencji dla zapewniania spójności (Polska Wschodnia) oraz - w miastach i innych obszarach tracacych dotychczasowe funkcje społeczno-gospodarcze (KSRR 2010: 158-159).

W systemie realizacji KSRR nie ma w zasadzie odniesień do przedsiębiorczości, przyjęto jedynie, że instytucje wdrożeniowe KSRR zakładają zdolność do wdrażania postępowań zintegrowanych o tak zwanym skomplikowanym charakterze, do których zaliczono między innymi przedsięwzięcia wymagające łączenia nauki z biznesem (KSRR 2010: 190). Warto zwrócić uwagę, że w KSRR nie ma żadnych odniesień do edukacji w zakresie przedsiębiorczości, choć jak wspomniano wcześniej, jej rola w opinii wielu badaczy wydaje się coraz większa. Wynika 
to $\mathrm{z}$ faktu, iż przedsiębiorczość została zaliczona do jednej z ośmiu tak zwanych kompetencji kluczowych w systemie edukacji (Dorocki, Borowiec-Gabryś 2014). W tym kontekście Z. Makieła (2013) wymienia jako jeden z celów szczegółowych działań na rzecz wzmocnienia przedsiębiorczości regionalnej, niezbędnych do prawidłowego rozwoju, wzmacnianie przedsiębiorczych i innowacyjnych umiejętności oraz postaw mieszkańców w celu wzmocnienia postaw konkurencyjnych, a także wspieranie programów rozwoju kreatywności i przedsiębiorczości dla dzieci i młodzieży oraz na uczelniach wyższych.

Choć z wniosków z prac tematycznych grup roboczych przygotowujących analizy i rekomendacje dla celów sformułowania KSRR wynikają jednoznaczne rekomendacje na rzecz stworzenia instrumentów wspierania rozwoju przedsiębiorczości w regionach, zapisy KSRR są w tym zakresie bardzo ogólnikowe i lakoniczne, a tym samym nie prowadzą do wzmacniania regionalnych środowisk przedsiębiorczości, które zdaniem A. Ochojskiego i in. (2005) w coraz większym stopniu wyznaczają kierunek rozwoju regionów, a ich tożsamość może dostarczać długotrwałej przewagi konkurencyjnej lub ją ograniczać.

\section{Zarys koncepcji funkcjonowania ,przedsiębiorczego regionu”}

W sytuacji marginalizacji roli przedsiębiorczości w KSRR wydaje się konieczne, aby zmienić cele i wzmocnić zapisy strategii odnoszące się do przedsiębiorczości, a także wdrożyć odpowiednie instrumenty, które przyspieszą rozwój regionalny. Zmiany te mogą opierać się na koncepcji ,przedsiębiorczego regionu”, czyli regionu:

- z wizją przedsiębiorczości (zapisaną w dokumentach strategicznych),

- aktywnego w zakresie przyciągnięcia zewnętrznych i wzmocnienia endogenicznych czynników rozwoju przedsiębiorczości, szczególnie sektora MŚP,

- opartego na systemie silnych powiązań między aktorami życia gospodarczego,

- wyposażonego w sprawnie działające instytucje i infrastrukturę otoczenia biznesu, jak również instytucje edukacyjne, wdrażające programy kształcenia w zakresie przedsiębiorczości z udziałem pracodawców na wszystkich poziomach edukacji formalnej i w kształceniu ustawicznym (lifelong learning).

Kształtowanie się i funkcjonowanie takiego regionu zachodzi w określonych uwarunkowaniach (ryc. 1): makroekonomicznych, politycznych, prawnych, a także tych wynikających z położenia geograficznego. Duży wpływ na jego funkcjonowanie ma również jakość systemu edukacji, głównie na poziomie uniwersyteckim, szczególnie jeśli instytucje szkolnictwa wyższego działają zgodnie z koncepcją ,uniwersytetu przedsiębiorczego" (Sam, van der Sijde 2014; Wiśniewska 2014; Wach 2014c).

Ważniejsze składowe tego typu regionu obejmują: wizję takiego regionu zapisaną w strategii, która odnosi się nie tylko do sektora przedsiębiorstw, lecz także obejmuje jego społeczność, zgodnie z nową, holistyczną perspektywą podejścia do planowania strategicznego, jakość przywództwa (zarządzania) i współrządzenia, sprawność administracji oraz zdolność do kooperacji z jednostkami niższego szczebla. Warto zwrócić uwagę, że taka wizja koncentruje się na szansach w otoczeniu, a nie na barierach do przezwyciężenia. Niezwykle ważną składową są innowacyjne, konkurencyjne przedsiębiorstwa, rozwijające się również w warunkach turbulencji otoczenia (tak jak w ostatnim czasie w latach ogólnoświatowego kryzysu gospodarczego), a także dobrze rozwinięta sieć instytucji otoczenia biznesu, w tym sektora $\mathrm{B}+\mathrm{R}$ oraz inkubatorów przedsiębiorczości. Kolejnym elementem tego typu regionu jest wysokiej jakości system edukacji, którego jednym z ważniejszych celów jest kształtowanie kreatywności i postaw przedsiębiorczych, a w konsekwencji wysokiej jakości, aktywnego kapitału ludzkiego, z dużym udziałem „,klasy kreatywnej” (por. Stryjakiewicz, Stachowiak 2010). 
Ryc. 1. Zarys koncepcji funkcjonowania „przedsiębiorczego regionu”

\begin{tabular}{|c|}
\hline $\begin{array}{l}\text { Uwarunkowania kształtowa- } \\
\text { nia się i funkcjonowania PReg }\end{array}$ \\
\hline $\begin{array}{l}\text { uwarunkowania makroekono- } \\
\text { miczne (światowe, europej- } \\
\text { skie, krajowe) }\end{array}$ \\
\hline $\begin{array}{c}\text { położenie geograficzne, } \\
\text { dostępność komunikacyjna } \\
\text { i sąsiedztwo }\end{array}$ \\
\hline $\begin{array}{l}\text { uwarunkowania polityczne, } \\
\text { w tym polityka UE i krajowa } \\
\text { w zakresie przedsiębiorczości } \\
\text { i rozwoju regionalnego }\end{array}$ \\
\hline $\begin{array}{l}\text { instrumenty prawne i do- } \\
\text { kumenty strategiczne (UE, } \\
\text { krajowe) }\end{array}$ \\
\hline $\begin{array}{c}\text { jakość systemu edukacji, } \\
\text { szczególnie na poziomie } \\
\text { uniwersyteckim, przygotowu- } \\
\text { jącego do życia w warunkach } \\
\text { GOW }\end{array}$ \\
\hline
\end{tabular}

\section{Uwarunkowania kształtowa-} nia się i funkcjonowania PReg

Źródło: opracowanie własne.

\section{PRZEDSIĘBIORCZY \\ REGION \\ (ważniejsze składowe)}

\begin{tabular}{|c|} 
wizja regionu przedsiębiorczego \\
zapisana w strategii
\end{tabular}

Skutki (efekty)

funkcjonowania PReg

wejśćie na ścieżkę ciągłego

rozwoju (podtrzymywalnego sustainable)

zmiana struktur regionalnych oraz awans gospodarczy, społeczny i kulturowy

korzystny wizerunek (image) regionu, prowadzący

do wzrostu jego atrakcyjności jako miejsca inwestycji i zamieszkania

wzrost konkurencyjności i kształtowanie marki regionu

poprawa jakości życia mieszkańców, m.in. poprzez większe możliwości inwestycji w poprawę warunków życia materialnego i duchowego

wzrost spójności terytorialnej i budowanie tożsamości regionalnej

W efekcie region taki wchodzi na ścieżkę ciągłego rozwoju (sustainable) i podnosi swoją konkurencyjność, gdyż przedsiębiorczość jest bez wątpienia jednym z nośników zdobywania i utrzymywania przewagi konkurencyjnej. Następuje zmiana struktur regionalnych, w tym struktury produkcji, wartości dodanej brutto i zatrudnienia. Wpływa to na korzystny wizerunek (image) regionu, prowadzący do wzrostu jego atrakcyjności jako miejsca inwestycji i zamieszkania, w efekcie czego kształtuje się jego marka. Ponadto następuje poprawa jakości życia mieszkańców, między innymi poprzez większe możliwości inwestycyjne w celu poprawienia warunków życia materialnego i duchowego, wzrasta też jego spójność terytorialna, a także budowana bądź rozwijana jest specyficzna tożsamość regionalna.

\section{Podsumowanie i wnioski}

Analiza zapisów KSRR wskazuje, że wdrażana z jej pomocą zmiana paradygmatu polityki regionalnej uwzględnia także zmianę instrumentów jej prowadzenia, co oznacza między innymi, że zamiast dotychczasowych subsydiów i pomocy publicznej koncentruje się ona na otoczeniu biznesowym, wprowadza także „nowych”, kluczowych aktorów tej polityki, między innymi przedstawicieli biznesu. W KSSR brak jest bezpośrednich odwołań do przedsiębiorczości w sformułowanych kluczowych jedenastu wyzwaniach i głównych celach, z wyjątkiem celów szczegółowych niższego rzędu: 1.3.3. Zwiększanie możliwości wprowadzania rozwiąań innowacyjnych przez przedsiębiorstwa i instytucje regionalne, 1.3.4. Wspieranie rozwoju instytucji otoczenia biznesu (IOB), natomiast nawiązania takie można znaleźć w opisach poszczególnych 
wyzwań, celów i kierunków działań. Szczególną uwagę zwrócono na rozwój przedsiębiorczości na obszarach wiejskich, zwłaszcza tych o utrudnionym rozwoju, i relatywnie sporo miejsca poświęcono potrzebie wsparcia instytucji otoczenia biznesu. W wielu wypadkach zapisy te mają jedynie charakter pewnych wtrąceń i uzupełnień, nie stanowią natomiast istoty danego celu czy działania. Nie uwzględniono zupełnie problematyki edukacji dla przedsiębiorczości w jakimkolwiek typie szkół, w tym także na poziomie uniwersyteckim czy kształcenia przez całe życie, choćby w odniesieniu do polityki oświatowej i szkolnictwa wyższego. Takie marginalne podejście do problematyki roli przedsiębiorczości w rozwoju regionów w podstawowym dokumencie polityki regionalnej należy uznać za nie najlepsze rozwiązanie, również ze względu na to, że w warunkach polskich nie sformułowano odrębnej, krajowej strategii rozwoju przedsiębiorczości.

W tej sytuacji konieczna wydaje się modyfikacja dokumentów strategicznych lub oparcie nowej strategii w kolejnym horyzoncie czasowym na koncepcji ,przedsiębiorczego regionu”. Wdrożenie takiej koncepcji jest uwarunkowane zastosowaniem podejścia strategicznego do polityki rozwoju regionalnego z punktem ciężkości położonym na kształtowanie przedsiębiorczych i jednocześnie konkurencyjnych regionów. Oznacza to, zdaniem A. Klasika (2005), formułowanie dwóch komplementarnych strategii regionalnych, czyli strategii przedsiębiorczej, koncentrującej się na stymulowaniu procesów kreacyjnych, i konkurencyjnej, wzmacniającej atrakcyjność regionu. Wydaje się więc konieczne, aby w dokumentach polityki regionalnej takie podejście, obejmujące nie tylko strategię podniesienia konkurencyjności, lecz także przedsiębiorczości regionów, było zastosowane. Warto również rozważyć wykorzystanie takiego podejścia w strategicznym programowaniu rozwoju poszczególnych regionów, zapisując je w strategiach wojewódzkich. Powinno się ono opierać na zastosowaniu szeregu wskaźników powiązanych z przedsiębiorczością, a nie tylko podstawowych wskaźników dotyczących liczby nowo powstałych czy zarejestrowanych firm przypadających na mieszkańca bądź ogólnej liczby ludności w wieku produkcyjnym.

\section{Literatura \\ References}

Acs, Z. (2010). Entrepreneurship and Regional Development. Cheltenham: Edward Elgar.

Barczyk, Z. (2004). Przedsiębiorczość i samorzadność lokalna. Chorzów: GWSP.

Berggren, E., Dahlstrand, A. L. (2009). Creating an Entrepreneurial Region: Two Waves of Academic Spin-offs from Halmstad University. European Planning Studies, 17(8), 1171-1189, DOI: 10.1080/09654310902981037.

Borowiec, M., Dorocki, S., Jenner, B. (2009). Wpływ zasobów kapitału ludzkiego na kształtowanie społeczeństwa informacyjnego i innowacyjności struktur przemysłowych. Prace Komisji Geografii Przemystu Polskiego Towarzystwa Geograficznego, 13, 95-109.

Brdulak, J., Jakubik, P. (2010). Instytucjonalne i kulturowe uwarunkowania przedsiębiorczości. W: K. Kuciński (red.), Przedsiębiorczość a rozwój regionalny w Polsce. Warszawa: Difin, 80-89.

Brzozowska, A., Glinka, B., Postuła, A. (2014). Role of University in Creating Entrepreneurial Attitudes. Horyzonty Wychowania, 13(26), 51-71.

Brzozowski, T. (2007). „Przedsiębiorczość” - pojęcie polisemiczne czy niewłaściwie rozumiane? Próba systematyzacji. Przedsiębiorczość - Edukacja, 3, 196-203.

Cieślik, J., Koładkiewicz, I. (2014). Wspieranie rozwoju przedsiębiorczości w aglomeracjach miejskich. Warszawa: Poltext.

Daszkiewicz, N. (2014). Education as a Stimulating Factor for Entrepreneurship Development. Horyzonty Wychowania, 13(26), 166-177. 
Dorocki, S., Borowiec-Gabryś, M. (2014). Problematyka przedsiębiorczości w programie studiów realizowanych w Uniwersytecie Pedagogicznym w Krakowie. Horyzonty Wychowania, 13(28), 65-80.

Dorocki, S., Brzegowy, P. (2014). Miejsce przedsiębiorczości w systemie edukacyjnym Francji i jej wpływ na aktywizację gospodarczą regionów. O idei l'esprit d'entreprise. Horyzonty Wychowania, 13(26), 287-302.

Dorocki, S., Jenner, B. (2009). Wpływ wielkości nakładów inwestycyjnych w sektorze B+R na regionalne zróżnicowanie tempa rozwoju Francji. Przedsiębiorczość - Edukacja, 5, 188-197.

Fritsch, M. (2011). Handbook of Research on Entrepreneurship and Regional Development: National and Regional Perspectives. Cheltenham: Edward Elgar.

Gal, Z. (2005). A New Tool for Economic Growth: Role of Innovation in the Transformation and Regional Development of Hungary. Geographia Polonica, 78(2), 31-52.

Gaweł, A. (2007). Ekonomiczne determinanty przedsiębiorczości. Poznań: Wydawnictwo Akademii Ekonomicznej.

Gaweł, A. (2013). Proces przedsiębiorczy. Tworzenie nowych przedsiębiorstw. Warszawa: Difin.

Georgellis, Y., Wall, H. J. (2000). What Makes a Region Entrepreneurial? Evidence from Britain. The Annals of Regional Science, 34(3), 385-403, DOI: 10.1007/s001689900014.

Glinka, B. (2008). Kulturowe uwarunkowania przedsiębiorczości w Polsce. Warszawa: PWE.

Golejewska, A. (2012). Innowacyjność a konkurencyjność regionalna krajów Grupy Wyszehradzkiej w latach 1999-2008. Prace Komisji Geografii Przemystu Polskiego Towarzystwa Geograficznego, $19,93-115$.

Hall, T., Hubbard, P. (1996). The Entrepreneurial City: New Urban Politics, New Urban Geographies? Progress in Human Geography, 20(2), 153-174, DOI: 10.1177/030913259602000201.

Jarczewski, W. (2007). Duch przedsiębiorczości w proinwestycyjnych działaniach władz lokalnych. Przedsiębiorczość - Edukacja, 3, 72-80.

Klasik, A. (2005). Przedsiębiorczość i konkurencyjność a rozwój regionalny. Kluczowe pojęcia i metodologia. Biuletyn Komitetu Przestrzennego Zagospodarowania PAN, 218, 7-22.

Kola-Bezka, M. (2010). Przyczynek do rozważań o przedsiębiorczości polskich regionów. Nierówności Społeczne a Wzrost Gospodarczy, 16, 403-411.

Kosała, M. (2015). Innovation Processes as a Stimulant of Internationalisation Process of Firms. Entrepreneurial Business and Economics Review, 3(2), 65-84, DOI: http://dx.doi.org/10.15678/ EBER.2015.030206.

Kuciński, K. (2010). Regionalna perspektywa przedsiębiorczości. W: K. Kuciński (red.), Przedsiębiorczość a rozwój regionalny w Polsce. Warszawa: Difin, 15-29.

Kurek, S., Rachwał, T. (2009). The Role of Business Education in the Development of Entrepreneurship in the Member States of the European Union. Europa XXI, 19, 127-142.

Makieła, Z. (2013). Przedsiębiorczość i innowacyjność terytorialna. Region w warunkach konkurencji. Warszawa: Wydawnictwo C. H. Beck.

Niedziółka, M. (2010). Przedsiębiorczość gminy a rozwój regionalny. W: K. Kuciński (red.), Przedsiębiorczość a rozwój regionalny w Polsce. Warszawa: Difin, 30-51.

Ochojski, A., Szczupak, B., Zieliński, T. (2005). Regionalne środowisko przedsiębiorczości. Problematyka badawcza. Biuletyn Komitetu Przestrzennego Zagospodarowania PAN, 218, 47-78.

Perło, D., Dębkowska, K. (2013). Konkurencyjność regionów Unii Europejskiej. Ekonomika i Organizacja Przedsiębiorstwa, 64(6), 60-70.

Płaziak, M., Rachwał, T. (2014). Kształcenie w zakresie przedsiębiorczości w polskich uniwersytetach na studiach nieekonomicznych (na przykładzie kierunku geografia). Horyzonty Wychowania, 13(26), 249-266.

Qian, H., Acs, Z. J., Stough, R. R. (2013). Regional Systems of Entrepreneurship: the Nexus of Human Capital, Knowledge and New Firm Formation. Journal of Economic Geography, 13(4), 559-587, DOI: $10.1093 / \mathrm{jeg} / \mathrm{lbs} 009$.

Rachwał, T., Płaziak, M. (2013). Przedsiębiorczość w kształceniu w zakresie gospodarki przestrzennej w polskich uniwersytetach. W: P. Churski, T. Kudłacz (red.), Gospodarka przestrzenna - doświadczenie $i$ wyzwania procesu kształcenia, Biuletyn Komitetu Przestrzennego Zagospodarowania Kraju PAN, 251, 198-263. 
Rantanen, T., Pawlak, A., Toikko, T. (2015). The Significance of Social Welfare Attitudes in Young People's Entrepreneurial Intentions. Entrepreneurial Business and Economics Review, 3(1), 43-60, DOI: http://dx.doi.org/10.15678/EBER.2015.030104.

Sam, C., van der Sijde, P. (2014). Understanding the Concept of the Entrepreneurial University from the Perspective of Higher Education Models. Higher Education, 68(6), 891-908, DOI: 10.1007/s10734014-9750-0.

Stryjakiewicz, T., Stachowiak, K. (2010). Uwarunkowania, poziom i dynamika rozwoju sektora kreatywnego w poznańskim obszarze metropolitalnym. Poznań: Bogucki Wydawnictwo Naukowe.

The European Entrepreneurial Region (EER), grudzień 2014, Encouraging Entrepreneurship at Local and Regional Level, http://cor.europa.eu/en/takepart/eer/Documents/EER\%20Leaflet\%202014-01. pdf.

Wach, K. (2007). Kształtowanie postaw przedsiębiorczych w programach nauczania. Stan obecny i proponowane kierunki zmian. W: P. Wachowiak, M. Dąbrowski, B. Majewski (red.), Kształtowanie postaw przedsiębiorczych a edukacja ekonomiczna. Warszawa: Fundacja Promocji i Akredytacji Kierunków Ekonomicznych, 120-127.

Wach, K. (2008). Regionalne otoczenie małych i średnich przedsiębiorstw. Kraków: Wydawnictwo Uniwersytetu Ekonomicznego.

Wach, K. (2013). Edukacja na rzecz przedsiębiorczości wobec współczesnych wyzwań cywilizacyjno-gospodarczych. Przedsiębiorczość - Edukacja, 9, 246-257.

Wach, K. (2014a). Paradygmat gospodarki przedsiębiorczej a polityka wspierania przedsiębiorczości. W: K. Zieliński (red.), Formy i przejawy współczesnej przedsiębiorczości w Polsce. Warszawa: Difin, $13-30$.

Wach, K. (2014b). Europeanisation of Entrepreneurship Education in Europe - Looking Back and Looking Forward. Horyzonty Wychowania, 13(26), 11-31.

Wach, K. (2014c). Edukacja dla przedsiębiorczości: pomiędzy przedsiębiorczą pedagogiką a edukacją ekonomiczną i biznesową. Horyzonty Wychowania, 13(28), 11-32.

Wach, K. (2015). Entrepreneurial Orientation and Business Internationalisation Process: The Theoretical Foundations of International Entrepreneurship. Entrepreneurial Business and Economics Review, 3(2), 9-24, DOI: http://dx.doi.org/10.15678/EBER.2015.030202.

Wiśniewska, D. (2014). Przedsiębiorczość uczelni wyższej jako wyzwanie współczesności - kierunki zmian. Horyzonty Wychowania, 13(28), 33-49.

Wyrwich, M. (2012). Regional Entrepreneurial Heritage in a Socialist and a Postsocialist Economy. Economic Geography, 88(4), 423-445, DOI: 10.1111/j.1944-8287.2012.01166.x.

Zheng, J. (2011). 'Creative Industry Clusters' and the 'Entrepreneurial City' of Shanghai. Urban Studies, 48(16), 3561-3582, DOI: 10.1177/0042098011399593.

Zioło, Z. (2012a). Miejsce innowacyjności w kształtowaniu procesów rozwoju gospodarczego układów przestrzennych. Prace Komisji Geografii Przemystu Polskiego Towarzystwa Geograficznego, 20, 9-32.

Zioło, Z. (2012b). Miejsce przedsiębiorczości w edukacji. Przedsiębiorczość - Edukacja, 8, 10-23.

Zioło, Z. (2013). Uwarunkowania rozwoju przedsiębiorczości w warunkach kryzysu gospodarczego. Przedsiębiorczość - Edukacja, 9, 10-33.

Zioło, Z., Rachwał, T. (2012). Entrepreneurship in Geographical Research. In: P. Churski (ed.), Contemporary Issues in Polish Geography. Poznań: Bogucki Wydawnictwo Naukowe, 135-155.

Monika Płaziak, dr, Uniwersytet Pedagogiczny im. Komisji Edukacji Narodowej w Krakowie, Instytut Geografii, Zakład Przedsiębiorczości i Gospodarki Przestrzennej. Jej zainteresowania badawcze dotyczą zagadnień gospodarki przestrzennej w kontekście czynników lokalizacji przedsiębiorstw, szczególnie czynnika personalnego. Prace badawcze odnoszą się również do zagadnień współpracy jednostek naukowych i badawczo-rozwojowych z sektorem MŚP, zwłaszcza w zakresie wdrażania nowych technologii i materiałów, w tym dotyczących budownictwa energooszczędnego i pasywnego. Ponadto zajmuje się problematyką poziomu i jakości życia ludności, 
ze szczególnym uwzględnieniem małych i średnich miast Polski oraz miast postsocjalistycznych, a także roli przedsiębiorczości w rozwoju regionalnych i lokalnych układów przestrzennych.

Monika Plaziak, PhD, Pedagogical University of Cracow, Institute of Geography, Department of Entrepreneurship and Spatial Management. Her research interests concern issues of the spatial development in the context of location factors of enterprises, especially - a personal factor. Monika Płaziak's research works also refer to issues of the cooperation of scientific and research-developmental organizations with the sector of small and medium-sized enterprises, especially within the area of implementing new technologies and materials concerning the energy-efficient and passive building. Furthermore, she analyses issues of the level and quality of life, with particular reference to small and medium-sized towns in Poland, and post socialist towns as well as the role of entrepreneurship in the development of regional and local spatial systems.

Tomasz Rachwal, dr, Uniwersytet Pedagogiczny im. Komisji Edukacji Narodowej w Krakowie, Instytut Geografii, Zakład Przedsiębiorczości i Gospodarki Przestrzennej. Członek Krajowej Rady Przedsiębiorczości. Pełni m.in. funkcję Kierownika Zakładu Przedsiębiorczości i Gospodarki Przestrzennej Instytutu Geografii Uniwersytetu Pedagogicznego w Krakowie, Sekretarza Naukowego Komisji Geografii Przemysłu Polskiego Towarzystwa Geograficznego, Zastępcy Redaktora Naczelnego czasopism: Przedsiębiorczość - Edukacja, Prace Komisji Geografii Przemystu Polskiego Towarzystwa Geograficznego, Annales Universitatis Paedagogicae Cracoviensis Studia Geographica oraz członka redakcji Entrepreneurial Business and Economics Review. Autor lub współautor podręczników szkolnych i akademickich z zakresu geografii ekonomicznej i przedsiębiorczości. Jego zainteresowania badawcze skupiają się przede wszystkim na problematyce przemian struktur przestrzennych przemysłu, funkcjonowania różnych branż działalności gospodarczej, restrukturyzacji przedsiębiorstw oraz roli przedsiębiorczości w rozwoju układów przestrzennych, a także edukacji w zakresie przedsiębiorczości.

Tomasz Rachwal, PhD, Pedagogical University of Cracow, Institute of Geography, Department of Entrepreneurship and Spatial Management. A member of the National Council for Entrepreneurship. A head of the Department of Entrepreneurship and Spatial Management of Institute of Geography of the Pedagogical University of Cracow, a Scientific Secretary of the Industrial Geography Commission of the Polish Geographical Society, A Deputy Editor in Chief of the following journals: Entrepreneurship -Education, Studies of the Industrial Geography Commission of the Polish Geographical Society, Annales Universitatis Paedagogicae Cracoviensis Studies Geographica, and a member of the editorial board of Entrepreneurial Business and Economics Review. The author or co-author of school and academic textbooks on economic geography and entrepreneurship. His research interests focus primarily on the issue of change of spatial structures of industry, the functioning of various branches of industrial activity, corporate restructuring and the role of entrepreneurship in the development of spatial systems as well as entrepreneurship education.

Adres/Address: Uniwersytet Pedagogiczny im. Komisji Edukacji Narodowej w Krakowie Instytut Geografii, Zakład Przedsiębiorczości i Gospodarki Przestrzennej ul. Podchorążych 2 30-084 Kraków, Polska e-mail: mplaziak@up.krakow.pl (Monika Płaziak), T.Rachwal@up.krakow.pl (Tomasz Rachwał) 